\title{
Temperature increase and its effects on fish stress physiology in the context of global warming
}

\author{
Alfonso Sébastien ${ }^{1,{ }^{\star}}$, Gesto Manuel ${ }^{2}$, Sadoul Bastien 3,4
}

${ }^{1}$ COISPA Tecnologia \& Ricerca, stazione sperimentale per lo studio delle risorse del mare, 70126

Bari ,Italy

${ }^{2}$ Section for Aquaculture, DTU Aqua Technical University of Denmark, Willemoesvej 2, 9850

Hirtshals ,Denmark

${ }^{3}$ MARBEC, Ifremer, IRD, UM2, CNRS, 34200 Sète ,France

${ }^{4}$ ESE, Ecology and Ecosystem Health, Institut Agro, INRAE, 35042 Rennes Cedex ,France

*Corresponding author : Sébastien Alfonso, email address : salfonso@coispa.eu

\begin{abstract}
:
The capacity of fishes to cope with environmental variation is considered to be a main determinant of their fitness and is partly determined by their stress physiology. By 2100 , global ocean temperature is expected to rise by $1-4^{\circ} \mathrm{C}$, with potential consequences for stress physiology. Global warming is affecting animal populations worldwide, through chronic temperature increases and an increase in the frequency of extreme heatwave events. As ectotherms, fishes are expected to be particularly vulnerable to global warming. Although little information is available about the effects of global warming on stress physiology in nature, multiple studies describe the consequences of temperature increases on stress physiology in controlled laboratory conditions, providing insight into what can be expected in the wild. Chronic temperature increase constitutes a physiological load than can alter the ability of fishes to cope with additional stressors, which might compromise their fitness. Besides, rapid temperature increases are known to induce acute stress responses in fishes and might be of ecological relevance in particular situations. This review summarizes knowledge about effects of temperature increases on the stress physiology of fishes, and discusses these in a context of global warming.
\end{abstract}

Keywords : heat, teleost, coping, cortisol, adaptive capacity, plasticity 


\section{1 | Introduction}

The capacity of a fish to cope with environmental change is driven by its ability to mount an adequate stress response, through the activation of physiological systems, the reallocation of energy towards defensive mechanisms and a behavioural change in order to cope with or avoid the environmental threat. The physiological mechanisms underlying these responses involve the activation of two main neuroendocrine pathways: the hypothalamic-pituitary-interrenal (HPI) axis, and the brain-sympathetic-chromaffin cell (BSC) axis, responsible for the production and release of cortisol and catecholamines, respectively (Wendelaar Bonga, 1997).

As ectotherms, fish body temperature is equivalent to their water temperature, with profound effects on their physiology, metabolism and behaviour (Clarke \& Johnston, 1999). Fish stress physiology is also affected by temperature in various ways. Firstly, the synthesis, release and actions of stress hormones are expected to be affected by temperature as a result of general thermodynamic effects on chemical reaction kinetics, according to the Boltzmann-Arrhenius model (Arrhenius, 1915; Boltzmann, 1972). In addition, a severe temperature increase can be a stressor in itself (Dengiz Balta et al., 2017; Samaras et al., 2018). Finally, acute or prolonged exposure to warm temperatures can alter function of the stress axes and responses to further stressors, possibly compromising the long-term coping capacity of the animal. This is particularly important because global warming is co-occurring with other elements of global change in aquatic habitats, such as ocean acidification and alterations in salinity (IPCC, 2014).

In the context of climate change, where seasonal water temperatures are increasing and thermal variations and extremes are becoming more frequent (Hoegh-Guldberg \& Bruno, 2010; Vasseur et 
al., 2014), a better understanding of the effects of temperature on stress physiology is crucial for predicting the consequences of global warming on the capacity of fish populations to persist. Little is known, however, about the impact of global warming on the two main stress axes, the HPI and BSC, in the wild. In this review, we provide an overview of the available information about the effects of temperature increase on fish stress physiology, mainly obtained in controlled laboratory conditions, and discuss the potential consequences for fitness and performance in a context of global warming.

\section{2 | Global warming and fish stress physiology}

\section{1 | The fish stress response}

In this review we adopt the functional definition of stress of Gorissen \& Flik (2016), being "a condition induced by a factor (a stressor) that evokes an endocrine response that could be beneficial as well as disadvantageous”. Indeed, stress is not inherently bad and an acute stress response can be viewed as an effective way to promote a physiological and/or behavioural change to better adapt to an environmental challenge and regain homeostasis. However, the physiological and behavioural adjustments generated by the stress response could be inappropriate in conditions where the stress repeated or sustained and cannot be avoided (Barton, 2002) and the animals cannot habituate to it.

Upon exposure to a stressor, various processes are initiated at different organizational levels (cells, tissue, organ, whole organism). The stress response is initiated by perception of a stimulus (internal or environmental) and its interpretation as a stressor (Schreck \& Tort, 2016) by the brain "stress centers”, believed to be located in the forebrain (mostly in the hypothalamus and the telencephalon) 
in fishes (Gorissen \& Flik, 2016). In the brain, the activity of monoaminergic neurotransmitters such as dopamine (DA), noradrenaline (NE) and, particularly, serotonin (5-HT), is likely involved in the organization and control of the stress state (Øverli et al., 2005; Gesto et al., 2013; Vindas et al., 2018). The brain orchestrates an integrated stress response largely following two different neuroendocrine pathways. The first comprises direct neural stimulation of the chromaffin cells in the anterior kidney (brain-sympathetic-chromaffin cell axis - BSC) (Wendelaar Bonga, 1997), resulting in the release of catecholamines into circulation. A second neuroendocrine route, the hypothalamus-pituitary-interrenal (HPI) axis, is more complex. Briefly, it starts with the activation of corticotropin releasing factor (CRF) neurons that discharge CRF into the pars distalis of the anterior pituitary. In there, CRF and other peptides (e.g. vasotocin) stimulate the release of adrenocorticotropic hormone (ACTH) into circulation, which in turn stimulates the production and release of cortisol (the main corticosteroid in teleosts) from the interrenal cells in the anterior kidney. (Sadoul \& Geffroy, 2019). Together, both sets of stress hormones, catecholamines and cortisol, have secondary actions in various tissues and organs that aim to increase the chances of the animal overcoming the stressor threat. Those actions include catecholamine-induced responses that are mainly directed towards making energetic substrates readily available to be used by muscle and other tissues to facilitate a behavioural response (Fabbri \& Moon, 2016), and cortisol-mediated changes (predominantly genomic, through the glucocorticoid (GR) and mineralocorticoid (MR) nuclear receptors), acting almost ubiquitously and believed to be directed towards mobilizing and reallocating energy substrates to facilitate adaptation (Faught et al., 2016; Sadoul \& Vijayan, 2016). 
When the stress becomes chronic or repeated, the reallocation of energy substrates could become detrimental for normal function of the fish. In such cases, long-term tertiary effects can arise, including negative effects on the immune system, growth or reproductive success. The net result of those would depend on the severity of the sustained stressor, but they can have consequences that extend to fish populations (Adams, 1990; Barton, 2002). In addition, prolonged exposure to stress and changes in circulating corticosteroids (mainly cortisol) may have long lasting effects on the stress physiology of the organism that influence the coping ability of their progeny (Colson et al., 2015, 2019; Redfern et al., 2017), recently referred to as the "quaternary stress response” (Faught et al., 2020).

\section{2 | Acute warming as an acute stressor for fishes}

Sudden exposure to high temperature is perceived as a stress by fishes, leading to the release of catecholamines and cortisol (LeBlanc et al., 2011; Cockrem et al., 2019). Cortisol responses during and after an acute temperature rise have been described for multiple species (Table 1), with only a few exceptions (e.g. LeBlanc et al. (2012); Chadwick et al. (2015)). Secondary stress responses are also observed upon acute temperature increase; glucose and lactate generally rise during acute thermal challenge, along with alterations in blood osmolality and other haematological variables (Dengiz Balta et al., 2017; Bard \& Kieffer, 2019). In addition, inhibitory effects on the fish immune system may be observed (Dengiz Balta et al., 2017). At the cellular level, Heat Shock Protein (HSPs) release is also modulated by the endocrine stress systems (Maloyan \& Horowitz, 2002; Currie et al., 2008). Briefly, the adrenergic system potentiated the HSP response in red blood cells of rainbow trout Oncorhynchus mykiss (Walbaum 1792) (Currie et al., 2008), while cortisol inhibited heat stress-induced levels of HSPs (Basu et al., 2001) (Figure 1). 
Global warming is increasing the frequency and severity of episodic and extreme marine heat waves (MHW; Meehl \& Tebaldi, 2004; Hoegh-Guldberg \& Bruno, 2010; Vasseur et al., 2014; Frölicher et al., 2018). It has been suggested that, in the context of global warming, these extreme events could be more relevant in driving population changes than a continuous increase in average temperatures (Vasseur et al., 2014; Sandblom et al., 2016). It is, however, difficult to know how frequently wild fish face abrupt changes in temperature. Fish are known to actively seek their preferred temperature (Larsson, 2005; Nivelle et al., 2019) but that might not always be feasible, depending on habitat characteristics and species biogeography. Consequently, although we think that protocols investigating laboratory induced acute (within hours) thermal shocks are worth being conducted in a context of fundamental research (e.g. to describe coping mechanisms) or aquaculture (e.g. to describe effects on welfare or productivity), scientists should be cautious when interpreting such results in a context of global warming.

\subsection{Prolonged exposure to elevated temperature and coping with stress}

\subsection{1 | Effects of chronic exposure to elevated temperature on resting stress physiology}

Living in warmer water has inherent effects on fish physiology since biochemical reaction rates are gulated by temperature (Somero, 2004). Therefore, physiological acclimation (or acclimatisation) to a higher temperature can be expected to enhance basal activity of HPI and BSC axes and basal release of stress hormones into cardiovascular circulation, as well as neurotransmitter activity. Such effects of temperature on biochemical reaction rates may be difficult to disentangle from effects generated by a chronic stress response. Nevertheless, we review evidence for the effects of prolonged increases in water temperature on the most common stress markers in fish. 
First, the brain catecholaminergic (noradrenergic and dopaminergic) systems may be altered under prolonged exposure to elevated temperature, which affects the synthesis, release and/or metabolization of their main neurotransmitters (NE and DA). For instance in common carp Cyprinus carpio L. 1758, both the level of a dopamine metabolite (3,4-dihydroxyphenylacetic acid, DOPAC) and the ratio between DOPAC and DA were greater in the hypothalamus and brain stem of fish held at elevated temperature for 2 weeks (30 vs $25^{\circ} \mathrm{C}$ ) (De Boeck et al., 1996), suggesting higher dopaminergic activity. In the Antarctic spiny plunderfish Harpagifer antarcticus Nybelin 1947, exposure to elevated temperature for 10 days $\left(11\right.$ vs $\left.2^{\circ} \mathrm{C}\right)$ induced an increase of DA in the brain (Vargas-Chacoff et al., 2019). In the same study, however, temperatures of 5 and $8{ }^{\circ} \mathrm{C}$ had no effect on brain DA levels, when compared to fish reared at $2{ }^{\circ} \mathrm{C}$. By contrast, exposure to higher temperature for two weeks (19 vs. 16 and $11^{\circ} \mathrm{C}$ ) induced a decrease of DA level in the brain of Chinook salmon Oncorhynchus tshawytscha (Walbaum 1792) (Giroux et al., 2019). This suggests that the response of the dopaminergic system to a temperature shift may depend on various different factors, such as duration of exposure, extent of temperature change, and species under study. Concerning the noradrenergic system, chronic exposure to elevated temperature triggers various different changes, depending on sex and brain regions (Tsai \& Wang, 1997). For instance, voth males and females Mozambique tilapia Oreochromis mossambicus (Peters 1852) acclimated to $32{ }^{\circ} \mathrm{C}$ (3 weeks) displayed higher level of NE in the hypothalamus than those reared at 26 or 29 ${ }^{\circ} \mathrm{C}$ (Tsai \& Wang, 1997). In the optic lobe, a similar increase in NE content was observed following acclimation to elevated temperature, but only in females. In the telencephalon, however, acclimation to high temperature lowered NE content in both males and females (Tsai \& Wang, 1997). 
The brain serotonergic system is believed to have an important role in organization of stress response in vertebrates (Winberg et al., 1997; Gesto et al., 2013; Puglisi-allegra \& Andolina, 2015). Several studies have reported modification of serotonergic activity following prolonged exposure to elevated temperature. In Cyprinus carpio, for instance, the main metabolite of serotonin (5-Hydroxyindoleacetic acid, 5-HIAA) was higher in both hypothalamus and brain stem (as for DOPAC) under elevated temperature (De Boeck et al., 1996). Consequently, greater serotonergic system activity was observed in brain stem of exposed fish (De Boeck et al., 1996). In Oreochromis mossambicus, 5-HT levels were affected by temperature increase in a manner that depended on sex and brain region (Tsai \& Wang, 1997). In Harpagifer antarcticus, the brain serotonin levels were enhanced upon exposure to both 8 and $11^{\circ} \mathrm{C}$ for 10 days, while the levels of the main metabolite of serotonin (5-hydroxyindole-3-acetic acid, 5HIAA) were not only dependent on temperature but also salinity (Vargas-Chacoff et al., 2019). Taken together these studies demonstrate that, in fishes, activity of various neurotransmitters is influenced by water temperature. Since monoaminergic neurotransmitters are important for physiological and behavioural stress coping, temperature-driven effects on stress physiology could be partly mediated through alterations to these brain stress pathways.

Prolonged exposure to high temperature may also induce changes in basal levels of stress hormones. As far as we know, the few studies investigating blood catecholamines have all reported little effect of acclimation temperatures (Milligan et al., 1989; Perry \& Reid, 1994). However, catecholamine-induced secondary responses such as the enhancement of blood haemoglobin and haematocrit were often observed in fish exposed to increased temperatures (Houston \& DeWilde, 1968; Houston \& Cyr, 1974) suggesting that transient catecholamine surges could help the fish to 
cope with a higher demand for oxygen. A putative negative feedback loop, consisting of catecholamines reducing sympathoadrenal activity, could be involved in the lack of changes in basal plasma catecholamines upon acclimation to high temperatures (Mravec, 2011), but the occurrence of such a loop remains to be demonstrated in fishes.

With regard to cortisol, basal blood levels are reported to be greater, overall, under prolonged exposure to elevated temperatures (Madaro et al., 2018; Samaras et al., 2018; Kim et al., 2019) (Figure 2). However, alternative results have occasionally been observed, as for example in the Emerald rockcod Trematomus bernacchii Boulenger 1902 that showed no changes in cortisol basal values upon acclimation to warmer water (up to $+3.8^{\circ} \mathrm{C}$ ) (Hudson et al., 2008) (Table 1). A negative feedback loop affecting cortisol production could underly the absence of increased basal cortisol in such cases (Mommsen et al., 1999). In Senegalese sole Solea senegalensis Kaup 1858, following the stress response observed upon sudden exposure to elevated temperature (24 vs. $18^{\circ} \mathrm{C}$ ), the cortisol level returned to basal level (i.e. similar to fish at $18^{\circ} \mathrm{C}$ ) (Benítez-Dorta et al., 2017). Cortisol levels then increased for a second time to a similar extent one week later. This midterm response was accompanied by an upregulation of glucocorticoid receptors and $c r f b p$ in the brain, acting as negative feedback on cortisol release (Benítez-Dorta et al., 2017). High circulating levels of cortisol are generally observed in parallel with the secondary stress response, observed as a change in plasma osmolality or an increase in blood glucose and lactate (Ryan, 1995; Steinhausen et al., 2008; Gallant et al., 2017; Kandalski et al., 2018; Samaras et al., 2018), but exceptions to that general pattern have been observed (Davis, 2004; Samaras et al., 2018).

Overall, living at warmer temperatures stimulates basal activity of monoamines in the central nervous system and the basal stress physiology of fishes. Whether these effects are the consequence 
of increased metabolic rates at high temperature or of a prolonged state of mild stress is still unclear. This could be investigated by comparing metabolic rate and basal levels of stress indicators at multiple temperatures.

\subsection{2 | Living in warmer environment alters stress coping capacities}

Prolonged exposure to elevated temperature due to global warming may affect the stress coping abilities of fishes, by impairing BSC and the HPI responses to further stressors. For example, the response of monoaminergic neurotransmitters to additional acute stress has been shown to be affected by elevated temperature in Cyprinus carpio, where the activity of both the dopaminergic and serotonergic systems was enhanced in specific brain regions (mainly in telencephalon) in response to a salinity challenge under elevated temperature (De Boeck et al., 1996), suggesting a temperature-induced shift of the stress response.

In response to hypoxia, catecholamines ( $\mathrm{E}$ and $\mathrm{NE}$ ) are released into the blood more rapidly and to higher levels in Oncorhynchus mykiss acclimated to $15^{\circ} \mathrm{C}$ compared to $5^{\circ} \mathrm{C}$ (Perry \& Reid, 1994). Upon acute stress, the peak of cortisol release and the dynamic to recover baseline level after stress may also be affected by water temperature. Briefly, the cortisol peak is achieved more rapidly, and hds to be of larger magnitude (Ryan, 1995; Davis, 2004; Madaro et al., 2018) (Figure 2). Other studies have however, found little effect of temperature on HPI responses (Lankford et al., 2003; Meka \& McCormick, 2005; Samaras et al., 2018; Vargas-Chacoff et al., 2020) (Table 2). This inconsistency could partly result from the difficulty of obtaining precise information on temporal response patterns for stress markers. Secondary stress response mechanisms are also generally 
enhanced in fish reared at warmer temperatures (Davis, 2004; Meka \& McCormick, 2005; Samaras et al., 2018).

Overall, the fish stress response to a challenge is faster and greater at elevated temperatures. Again, whether this is the consequence of an increased overall metabolic rate or changes in coping ability is still unclear. Understanding the fitness consequences of such effects of warmer temperatures is primordial for investigating the impacts on fish populations, especially since fishes are exposed to a wide range of acute stressors during their life and more particularly in the context of global warming.

\section{4 | Thermal imprinting and the fish stress response}

Empirical studies in fishes have demonstrated that early exposure to other stressors induces plasticity of the HPI axis upon further stress exposure (Varsamos et al., 2006; Auperin \& Geslin, 2008). Since prolonged exposure to elevated temperature may be perceived as a stressor, exposure at early life stages, particularly during embryonic development, may trigger similar long-lasting effects on individual physiology and subsequent ability to cope with similar or novel environmental challenges. This phenomenon is generally known as 'thermal imprinting' (Steinbacher et al., 2011;

ateus et al., 2017a). Adult Gilthead seabream Sparus aurata L. 1758 reared at high temperatures during development (embryo and larvae) showed, for example, a reduced cortisol response to a confinement stress, despite an identical thermal history during the post-larval stage (Mateus et al., 2017a). Their stress reactivity to a cold challenge was also greater in those reared at high temperature during the embryonic stage (Mateus et al., 2017b). Changes in the transcription of key 
genes involved in regulation of the HPI axis (e.g. $g r$, pomca2) were also observed in response to thermal imprinting, which may partly explain the changes in coping abilities (Mateus et al., 2017a).

The biological processes by which stress physiology and the fish physiology in general are altered in the long term, due to prior exposure to elevated temperature, are not yet fully understood. Sustained changes in brain monoaminergic signalling and neural plasticity in specific areas, or epigenetic modifications, may contribute to observed effects (Zhang et al., 2010; Fokos et al., 2017; Vindas et al., 2018). In the context of global warming, epigenetic modifications may be induced by exposure to elevated temperature (Bizuayehu et al., 2015; Anastasiadi et al., 2017; Jonsson \& Jonsson, 2019), that can later mediate the coping ability of individuals upon stress.

Prolonged exposure to elevated temperature at early life stages may therefore have long-term consequences for stress physiology, potentially modifying the ability to cope with additional stressors. Whether these modifications are adaptive in a context of global warming remains to be understood. Further research is also required to better understand the complex interrelationship between timing, amplitude and duration of the thermal increase during thermal imprinting in fishes, and the consequences for fitness traits.

\section{Stress, energy and global warming: Potential consequences for fish populations}

Global warming has already been demonstrated to alter fish populations, through changes in local abundance, extinctions or migrations towards colder areas (Payne, 2013; Burrows et al., 2019; Free et al., 2019). But what is the proximate cause of such alterations? Indirect effects of temperature increase, including alterations in prey-predator interactions or reduced oxygen availability

(Breitburg et al., 2018) also contribute to global warming-induced modifications of fish 
populations. However, a direct physiological effect of temperature is believed to be the primary mechanism behind population shifts (Pörtner \& Knust, 2007; Pörtner \& Farrell, 2008). This main direct effect seems to be related to global warming taking fish closer to, or beyond, their upper thermal-tolerance limits (Dillon et al., 2010; Eliason et al., 2011; Pinsky et al., 2019). Furthermore, warming may particularly affect stenothermal species, typical of tropical or polar latitudes (Somero, 2010; Comte \& Olden, 2017). For these species, an inability to tolerate temperature fluctuations and warming might be a particularly life-threatening challenge (Somero, 2010; Faught et al., 2020). However, the physiological traits that determine thermal tolerance are not entirely understood. Protection against heat at the cellular level involves the synthesis of chaperone proteins, the HSPs, that are highly conserved in the animal kingdom (Margulis et al., 1989). The HSPs prevent protein aggregation, refolding of stress-denatured proteins and apoptosis and cell death (Roberts et al., 2010). Multiple studies have found a link between the ability to upregulate HSPs and thermal tolerance in aquatic species (Fangue et al., 2006; Shatilina et al., 2011; Feidantsis et al., 2013; Blair \& Glover, 2019), indicating a potential ecological relevance of HSPs in a context of global warming.

From an energetic point of view, warming is costly, for multiple reasons. Firstly, due to thermal acceleration of metabolic rates (Dell et al., 2011), physiological and behavioural processes are stimulated, leading to faster development times, growth, or swimming activity (Pauly, 1980; Kent \& Ojanguren, 2015; Tsoukali et al., 2016). Together, this causes energy demands to increase, energy that must be more actively obtained from the environment (Figure 3.b). In general, these thermal conditions do not translate into energetic stress for the fish as long as the environment can provide sufficient food. Nevertheless, when temperature continues to increase, additional 
maintenance is needed at the cellular level (Figure 3.c), with the need to counteract the detrimental effects of temperature, including protein denaturation, DNA mutations, oxidative damage and ultimately cellular death (Lepock, 2005). Fish enters then a "stressed state", with non-critical functions (reproduction, growth or immunity) slowed down to compensate for these new immediate needs (Sadoul \& Vijayan, 2016).

Applying an additional stressor to this energetic framework can be expected to be particularly detrimental to the animal, since stress can reduce energy availability by lowering feeding activities and increasing somatic maintenance (Sadoul \& Vijayan, 2016). Global warming can therefore be expected to exacerbate energetic constraints in a generally more stressful world, particularly because animal basal metabolic rates increase exponentially with temperature (Gillooly et al., 2001; Dillon et al., 2010), while maximum metabolic capacity often stops increasing or declines at high temperatures (Clarke \& Johnston, 1999; Norin \& Clark, 2016; Sandblom et al., 2016), This ultimately leads to a reduced scope to support non-essential activities (Navarro et al., 2019). This is suspected to be one of the main reason why local fish populations can be reduced or even extirpated from specific locations, particularly when populations or subpopulation are tightly adapted to specific environmental conditions (Eliason et al., 2011). Chadwick et al. (2015) observed a concordance between upper thermal limit of Brook trout Salvelinus fontinalis (Mitchill 1814) and the temperature that induced a physiological stress response, suggesting that the stress threshold could be a major driver of fish distribution for this species. This highlights the pivotal role of stress physiology in the context of global warming (Chadwick \& McCormick, 2017).

In addition, the effects of global warming on stress physiology can also have ramifications for other aspects of fish biology, such as reproduction or immunity. For example, changes in HPI regulation, 
and more particularly glucocorticoid levels during early life stages, may have profound long term consequences for the organism, including effects on sex determination (Geffroy \& Douhard, 2019; Geffroy \& Wedekind, 2020). Increased temperatures can also alter host-parasite interactions, resulting in higher occurrence and severity of infections (Marcos-Lopez et al., 2010). These effects can be partially mediated by stress-induced immune alterations (Tort, 2011; Yada \& Tort, 2016). Those alterations include immune depression and higher susceptibility to infection and disease (Kandalski et al., 2018; Martínez et al., 2018; Kim et al., 2019; Li et al., 2019). In addition, it is important to note that global warming can lead to the emergence of novel infectious agents, triggering diseases for which fishes are not yet adapted (Marcos-López et al., 2010).

Stress physiology is also involved in hydromineral balance and maintenance of ionic homeostasis (Barton \& Schreck, 1987; Geering, 1990). Consequently, alteration in stress physiology due to global warming may have consequences for these regulatory homeostatic processes (Kandalski et al., 2018), and the central role of cortisol in these effects was recently suggested (Samaras et al., 2018; Vargas-Chacoff et al., 2020).

In addition, the levels of cortisol and/or neurotransmitter activity are well known to mediate fish behaviour (Øverli et al., 2002, 2004). Therefore, changes in fish behaviour can be expected at higher temperature, due to changes in stress physiology machinery, with potential cascading effect on populations. On the first hand, changes in neurotransmission may alter social behaviour of fish, affecting intra- and interspecies interactions that can affect the functioning of ecosystems under a warmer environment (Allan et al., 2017; Paula et al., 2019). On the other hand, an increase of locomotor activity, boldness and aggressive behaviour have been frequently observed for fish at higher temperature (Biro et al., 2010; Angiulli et al., 2020). It is suggested that these changes 
allow fish to get higher access to food sources (for compensating higher metabolic rates), but this also makes them more vulnerable to predation (Biro et al., 2007).

It is also worth mentioning that warmer temperatures can enhance the severity of other stressors. One example is the increase in the prevalence and/or severity of diseases commented above (Marcos Lopez et al., 2010). Another example is the general increase in the toxicity of water-borne pollutants (Noyes et al., 2009).

In summary, chronic temperature increase can act in three ways to affect fish populations, from the point of view of stress. It can be a stressor itself, altering responses to further stressors, and it can actually generate "new” or enhanced stressors for fish populations. Therefore, global warming will cause a multi-stressor environment for wild fish populations, potentially leading to serious reduction in their fitness. It has been hypothesized that, in the context of exposure to multiple stressors, fish populations could change coping strategy (shutting off stress response for maintaining growth and metabolic routines), negatively affecting fitness and survival (Petitjean et al., 2019).

\section{4 | Conclusions and perspectives}

Global warming is now a reality challenging fishes with an increase in seasonal water temperatures and the occurrence of extreme heatwave events. Stress physiology has a pivotal role in coping with environmental changes, including global warming. We reviewed the effects of acute and chronic increases in water temperature on fish stress physiology. Upon chronic temperature increase, all metabolic reactions are enhanced in ectotherms. Nevertheless, the high levels of stress-related reactions observed during long term exposure to high temperature might be because the fish 
perceives the conditions as a chronic stress. Very little information is available to disentangle whether high cortisol levels and changes in neurotransmitter activity are the consequences of increased metabolism or a response to chronic stress.

We explain in this review how global warming can lead to energy limitation through stress physiology, and ultimately modifies the sensitivity to other environmental stressors in fishes (Stiasny et al., 2019; Cominassi et al., 2020). This is of primary interest since, in addition to global warming, aquatic habitats are also suffering from acidification, hypoxia, chemical pollution, and so forth (Sih, 2013; Gordon et al., 2018). Overcoming the load induced by a multi-stressor environment might be difficult under normal conditions, but will be even more complicated in a warmer world, due to limitations in energy available. Since the interactions between two or more stressors are complex to predict (Piggott et al., 2015; Jackson et al., 2016; Liess et al., 2016), multistressors studies are needed to better understand how fish populations will be affected by global warming (Côté et al., 2016).

The thermal experience of fish, especially during early life, can shape the HPI responsiveness upon further stressors (Mills et al., 2015; Mateus et al., 2017a). A research effort is needed to understand how exposure to elevated temperatures during early life may affect capacity to cope with the various threats caused by global warming (Whitney et al., 2013; Mateus et al., 2017a; Wassink et al., 2019). Furthermore, in the context of global warming, recent multi-generational studies showed that, after acclimation of one or two generations to elevated temperatures, the progeny were often better able to tolerate higher temperatures, in particular by decreasing their metabolic rate (Donelson et al., 2012; Bernal et al., 2018; Ryu et al., 2018; Pilakouta et al., 2020). Further studies 
must elucidate how this relates to stress physiology and further capacities to cope with additional stressors.

It is difficult to generalize about the vulnerability of fishes to global warming since their response will depend on multiple factors, including their natural distribution, their intrinsic metabolic capacities, their life history or genetic background (Somero, 2010; Comte \& Olden, 2017; Colossi Brustolin et al., 2019). Besides, fish species or individuals differ considerably in the magnitude of their responses to specific stressors, (Mommsen et al., 1999; Barton, 2002), including increased temperature (LeBlanc et al., 2012; Madeira et al., 2013). Whether this differential sensitivity to stress might pose an advantage or disadvantage for certain individuals or species, in a warmer future, is not known. We argue that this requires a major research effort, to correctly predict consequences for ecosystems, fisheries and aquaculture (Froehlich et al., 2018).

\section{Acknowledgments}

We would like to thank Anthony Farrell, Benjamin Geffroy and David J. McKenzie for kindly inviting us to submit this review paper. We also thank the two anonymous reviewers, as well as

David J. McKenzie, for their constructive comments on the previous version of this manuscript.

\section{References}

Adams, S. M. (1990). Biological indicators of stress in fish. In American Fisheries Society Symposium Series p. Series 8 Bethesda, Maryland.

Allan, B. J. M., Domenici, P., Watson, S. A., Munday, P. L., \& McCormick, M. I. (2017). Warming has a greater effect than elevated CO2 on predator-prey interactions in coral reef Fish. Proceedings of the Royal Society B: Biological Sciences, 284, 1-9.

Anastasiadi, D., Díaz, N., \& Piferrer, F. (2017). Small ocean temperature increases elicit stagedependent changes in DNA methylation and gene expression in a fish, the European sea bass. Scientific Reports, 7, 1-12. 
Angiulli, E., Pagliara, V., Cioni, C., Frabetti, F., Pizzetti, F., Alleva, E., \& Toni, M. (2020). Increase in rnvironmental temperature affects exploratory behaviour, anxiety and social Preference in Danio Rerio. Scientific Reports, 10, 1-12.

Arrhenius, S. (1915). Quantitative laws in biological chemistry. G. Bell and Sons, Ltd.

Auperin, B., \& Geslin, M. (2008). Plasma cortisol response to stress in juvenile Rainbow trout is influenced by their life history during early development and by egg cortisol content. General and Comparative Endocrinology, 158, 234-239.

Bard, B., \& Kieffer, J. (2019). The effects of repeat acute thermal stress on the critical thermal maximum (CTmax) and physiology of juvenile shortnose sturgeon Acipenser Brevirostrum. Canadian Journal of Zoology, 97, 567-572.

Barton, B. A. (2002). Stress in fishes: A diversity of responses with particular reference to changes in circulating corticosteroids. Integrative and Comparative Biology, 42, 517-525.

Barton, B. A., \& Schreck, C. B. (1987). Influence of acclimation temperature on interrenal and carbohydrate stress responses in juvenile Chinook salmon (Oncorhynchus Tshawytscha). Aquaculture, 62, 299-310.

Basu, N., Nakano, T., Grau, E. G., \& Iwama, G. K. (2001). The effects of cortisol on heat shock protein 70 levels in two fish species. General and comparative endocrinology, 124, 97-105.

Benítez-Dorta, V., Caballero, M. J., Betancor, M. B., Manchado, M., Tort, L., Torrecillas, S., ... Montero, D. (2017). Effects of thermal stress on the expression of glucocorticoid receptor complex linked genes in Senegalese Sole (Solea Senegalensis): acute and adaptive stress responses. General and Comparative Endocrinology, 252, 173-185.

Bernal, M. A., Donelson, J. M., Veilleux, H. D., Ryu, T., Munday, P. L., \& Ravasi, T. (2018). Phenotypic and molecular consequences of stepwise temperature increase across generations in a Coral Reef Fish. Molecular Ecology, 27, 4516-4528.

Biro, P. A., Post, J. R., \& Booth, D. J. (2007). Mechanisms for climate-induced mortality of fish populations in whole-lake experiments. Proceedings of the National Academy of Sciences of the United States of America, 104, 9715-9719.

Biro, P. A., Beckmann, C., \& Stamps, J. A. (2010). Small within-day increases in temperature Affects Boldness and Alters Personality in Coral Reef Fish. Proceedings of the Royal Society B: Biological Sciences, 277, 71-77.

Bizuayehu, T. T., Johansen, S. D., Puvanendran, V., Toften, H., \& Babiak, I. (2015). Temperature during early development has long-term effects on MicroRNA expression in Atlantic Cod. BMC Genomics, 16, 1-12.

Blair, S. D., \& Glover, C. S. (2019). Acute exposure of larval rainbow trout (Oncorhynchus Mykiss) to elevated temperature limits Hsp70b expression and influences future thermotolerance. Hydrobiologia, 836, 155-167.

Boltzmann, L. (1972). Weitere studien uber das warmegleich- gewicht unter gasmolekulen. 
Berichte Wiene, 66, 275-370.

De Boeck, G., Nilsson, G. E., Vlaeminck, A., \& Blust, R. (1996). Central monoaminergic responses to salinity and temperature rises in Common Carp. Journal of Experimental Biology, 199, 1605-1611.

Breitburg, D., Levin, L. A., Oschlies, A., Grégoire, M., Chavez, F. P., Conley, D. J., ... Zhang, J. (2018). Declining oxygen in the global ocean and coastal waters. Science, 359.

Burrows, M. T., Bates, A. E., Costello, M. J., Edwards, M., Edgar, G. J., Fox, C. J., ... Poloczanska, E. S. (2019). Ocean community warming responses explained by thermal affinities and temperature gradients. Nature Climate Change, 9, 959-963.

Chadwick, J. G., \& McCormick, S. D. (2017). Upper thermal limits of growth in Brook trout and their relationship to stress physiology. Journal of Experimental Biology, 220, 3976-3987.

Chadwick, J. G., Nislow, K. H., \& McCormick, S. D. (2015). Thermal onset of cellular and endocrine stress responses correspond to ecological limits in Brook trout, an iconic cold-water fish. Conservation Physiology, 3, 1-12.

Clarke, A., \& Johnston, N. M. (1999). Scaling of metabolic rate with body mass and temperature in teleost fish. Journal of Animal Ecology, 68, 893-905.

Cockrem, J. F., Bahry, M. A., \& Chowdhuryd, V. S. (2019). cortisol responses of goldfish (Carassius Auratus) to air exposure, chasing, and increased water temperature. General and Comparative Endocrinology, 270, 18-25.

Colossi Brustolin, M., Nagelkerken, I., Moitinho Ferreira, C., Urs Goldenberg, S., Ullah, H., \& Fonseca, G. (2019). Future ocean climate homogenizes communities across habitats through diversity loss and rise of generalist species. Global Change Biology, 25, 3539-3548.

Colson, V., Cousture, M., Damasceno, D., Valotaire, C., Nguyen, T., Le Cam, A., \& Bobe, J. (2019). Maternal temperature exposure impairs emotional and cognitive responses and triggers dysregulation of neurodevelopment genes in fish. PeerJ, 2019.

Colson, V., Valotaire, C., Geffroy, B., \& Kiilerich, P. (2015). Egg cortisol exposure enhances fearfulness in larvae and juvenile Rainbow trout. Ethology, 121, 1191-1201.

Cominassi, L., Moyano, M., Claireaux, G., Howald, S., Mark, F. C., Zambonino-Infante, J. L., \& Peck, M. A. (2020). Food availability modulates the combined effects of ocean acidification and warming on fish growth. Scientific reports, 10, 2338.

Comte, L., \& Olden, J. D. (2017). Climatic vulnerability of the world's freshwater and marine fishes. Nature Climate Change, 7, 718-722.

Côté, I. M., Darling, E. S., \& Brown, C. J. (2016). Interactions among ecosystem stressors and their importance in conservation. Proceedings of the Royal Society B: Biological Sciences, 283, 19.

Currie, S., Reddin, K., McGinn, P., McConnell, T., \& Perry, S. F. (2008). $\beta$-Adrenergic stimulation 
enhances the heat-shock response in fish. Physiological and Biochemical Zoology, 81, 414425.

Davis, K. B. (2004). Temperature Affects physiological stress responses to acute confinement in Sunshine bass (Morone Chrysops $\times$ Morone Saxatilis). Comparative Biochemistry and Physiology - A Molecular and Integrative Physiology, 139, 433-440.

Dell, A. I., Pawar, S., \& Savage, V. M. (2011). Systematic variation in the temperature dependence of physiological and ecological traits. Proceedings of the National Academy of Sciences of the United States of America, 108, 10591-10596.

Dengiz Balta, Z., Akhan, S., \& Balta, F. (2017). The physiological stress response to acute thermal exposure in Black sea trout (Salmo Trutta Labrax Pallas, 1814). Turkish Journal of Veterinary and Animal Sciences, 41, 400-406.

Dillon, M. E., Wang, G., \& Huey, R. B. (2010). Global metabolic impacts of recent climate warming. Nature, 467, 704-706.

Donelson, J. M., Munday, P. L., McCormick, M. I., \& Pitcher, C. R. (2012). Rapid transgenerational acclimation of a tropical reef fish to climate change. Nature climate change, 2, 30-32.

Eliason, E. J., Clark, T. D., Hague, Merran, J., Hanson, L. M., Gallagher, Z. S., Jeffries, K. M., ... Farrell, A. P. (2011). Differences in thermal tolerance among Sockeye salmon populations. Science, 332, 109-112.

Fabbri, E., \& Moon, T. W. (2016). Adrenergic signaling in teleost fish liver, a challenging path. Comparative Biochemistry and Physiology Part B: Biochemistry and Molecular Biology, 199, 74-86.

Fangue, N. A., Hofmeister, M., \& Schulte, P. M. (2006). Intraspecific variation in thermal tolerance and heat shock protein gene expression in common Killifish, Fundulus heteroclitus. Journal of Experimental Biology, 209, 2859-2872.

Faught, E., Aluru, N., \& Vijayan, M. M. (2016). The molecular stress eesponse. Elsevier Inc. Vol. 35.

Faught, E., Hernandez-Perez, J., Wilson, Jonathan, M., \& Vijayan, M. M. (2020). Stress response to environmental changes. In Climate Change and Non-infectious Fish Disorders (Iwama, E. by P. T. K. Z. and G. K., ed), pp. 136-162.

Feidantsis, K., Antonopoulou, E., Lazou, A., Pörtner, H. O., \& Michaelidis, B. (2013). Seasonal variations of cellular stress response of the Gilthead sea bream (Sparus Aurata). Journal of Comparative Physiology B: Biochemical, Systemic, and Environmental Physiology, 183, 625639.

Fokos, S., Pavlidis, M., Yiotis, T., Tsalafouta, A., Papandroulakis, N., \& Dermon, C. R. (2017). Early life low intensity stress rxperience modifies acute stress effects on juvenile brain Cell Proliferation of European Sea Bass (D. Labrax). Elsevier B.V. Vol. 317. 
Free, C. M., Thorson, J. T., Pinsky, M. L., Oken, K. L., Wiedenmann, J., \& Jensen, O. P. (2019). Impacts of historical warming on marine fisheries production. Science, 363, 979.983.

Froehlich, H. E., Gentry, R. R., \& Halpern, B. S. (2018). Global change in marine aquaculture production potential under climate change. Nature Ecology \& Evolution.

Frölicher, T. L., Fischer, E. M., \& Gruber, N. (2018). Marine heatwaves under global warming. Nature, 560, 360-364.

Gallant, M. J., LeBlanc, S., MacCormack, T. J., \& Currie, S. (2017). Physiological responses to a short-term, environmentally realistic, acute heat dtress in Atlantic dalmon, Salmo salar . Facets, 2, 330-341.

Geering, K. (1990). Subunit assembly and functional maturation of Na,K-ATPase. The Journal of Membrane Biology, 115, 109-121.

Geffroy, B., \& Douhard, M. (2019). The adaptive sex in stressful environements. Trends in Ecology \& Evolution, 34 (7), 628-640.

Geffroy, B., \& Wedekind, C. (2020). Effects of global warming on sex ratios in fishes. Journal of Fish Biology, 97, 596-606.

Gesto, M., Lopez-Patino, M. A., Hernandez, J., Soengas, J. L., \& Miguez, J. M. (2013). The response of brain serotonergic and dopaminergic systems to an acute stressor in rainbow trout: a time course study. Journal of Experimental Biology, 216, 4435-4442.

Gillooly, J. F., Brown, J. H., West, G. B., Savage, V. M., \& Charnov, E. L. (2001). Effects of size and temperature on metabolic rate. Science, 293, 2248-2251.

Giroux, M., Vliet, S. M. F., Volz, D. C., Gan, J., \& Schlenk, D. (2019). Mechanisms behind interactive effects of temperature and bifenthrin on the predator avoidance behaviors in parr of Chinook salmon (Oncorhynchus tshawytscha ). Aquatic Toxicology, 216, 105312.

Goikoetxea, A., Sadoul, B., Blondeau-Bidet, E., Aerts, J., Blanc, M. O., Parrinello, H., ... Geffroy, B. (2021). Genetic pathways underpinning hormonal stress responses in fish exposed to shortand long-term warm ocean temperatures. Ecological Indicators, 120, 106937.

Gordon, T. A. C., Harding, H. R., Clever, F. K., Davidson, I. K., Davison, W., Montgomery, D. W., ... Santos, E. M. (2018). Fishes in a changing world: learning from the past to promote sustainability of fish populations. Journal of Fish Biology, 92, 804-827.

Gorissen, M., \& Flik, G. (2016). The endocrinology of the stress response in fish: An adaptationphysiological View. Fish Physiology, 35, 74-111.

Hoegh-Guldberg, O., \& Bruno, J. F. (2010). The impact of climate change on the world's marine ecosystems. Science, 328, 1523-1528.

Houston, A. H., \& Cyr, D. (1974). Thermoacclimatory variation in the haemoglobin systems of goldfish (Carassius auratus) and Rainbow trout (Salmo gairdneri). Journal of Experimental Biology, 61, 455-461. 
Houston, A. H., \& DeWilde, M. A. (1968). Thermoacclimatory variations in the haematology of the common Carp, Cyprinus carpio. Journal of Experimental Biology, 49, 71-81.

Hudson, H. A., Brauer, P. R., Scofield, M. A., \& Petzel, D. H. (2008). Effects of warm acclimation on serum osmolality, cortisol and hematocrit levels in the Antarctic fish, Trematomus Bernacchii. Polar Biology, 31, 991-997.

IPCC. (2014). Climate Change 2014: Synthesis report. contribution of working groups I, II and III to the fifth assessment report of the intergovernmental panel on climate change. Geneva, Switzerland.

Jackson, M. C., Loewen, C. J. G., Vinebrooke, R. D., \& Chimimba, C. T. (2016). Net effects of multiple stressors in freshwater ecosystems: a meta-analysis. Global Change Biology, 22, 180-189.

Jonsson, B., \& Jonsson, N. (2019). Phenotypic plasticity and epigenetics of fish: embryo temperature affects later-developing life-history traits. Aquatic Biology, 28, 21-32.

Kandalski, P. K., de Souza, M. R. D. P., Herrerias, T., Machado, C., Zaleski, T., Forgati, M., ... Donatti, L. (2018). Effects of short-Term thermal stress on the plasma biochemical profiles of two Antarctic Nototheniid species. Reviews in Fish Biology and Fisheries, 28, 925-940.

Kent, M., \& Ojanguren, A. F. (2015). The effect of water temperature on routine swimming behaviour of new born Guppies (Poecilia reticulata). Biology Open, 4, 547-552.

Kim, J. H., Kim, S. K., \& Hur, Y. B. (2019). Temperature-mediated changes in stress responses, acetylcholinesterase, and immune responses of juvenile Olive flounder Paralichthys Olivaceus in a bio-floc environment. Aquaculture, 506, 453-458.

Lankford, S. E., Adams, T. E., \& Cech, J. J. (2003). Time of day and water temperature modify the physiological stress response in green Sturgeon, Acipenser medirostris. Comparative Biochemistry and Physiology - A Molecular and Integrative Physiology, 135, 291-302.

Larsson, S. (2005). Thermal preference of Arctic charr, Salvelinus alpinus, and Brown trout, Salmo trutta - Implications for their niche segregation. Environmental biology of fishes, 73, 89-96.

BBlanc, S., Middleton, S., Gilmour, K. M., \& Currie, S. (2011). Chronic social stress impairs thermal tolerance in the Rainbow trout (Oncorhynchus mykiss). Journal of Experimental Biology, 214, 1721-1731.

LeBlanc, S., Höglund, E., Gilmour, K. M., \& Currie, S. (2012). Hormonal modulation of the heat shock response: insights from fish with divergent cortisol stress responses. American Journal of Physiology - Regulatory Integrative and Comparative Physiology, 302, 184-192.

Lepock, J. R. (2005). How do cells respond to their thermal environment ? International journal of hyperthermia, 21, 681-687.

Li, B., Sun, S., Zhu, J., Yanli, S., Wuxiao, Z., \& Ge, X. (2019). Transcriptome profiling and histology changes in juvenile blunt snout bream (Megalobrama amblycephala) liver tissue in response to acutethermal stress. Genomics, 111, 242-250. 
Liess, M., Foit, K., Knillmann, S., Schäfer, R. B., \& Liess, H. D. (2016). Predicting the synergy of multiple stress effects. Scientific Reports, 6, 1-8.

Madaro, A., Folkedal, O., Maiolo, S., Alvanopoulou, M., \& Olsen, R. E. (2018). Effects of acclimation temperature on cortisol and oxygen consumption in Atlantic salmon (Salmo salar) post-smolt exposed to acute stress. Aquaculture, 497, 331-335.

Madeira, D., Narciso, L., Cabral, H. N., Vinagre, C., \& Diniz, M. S. (2013). Influence of temperature in thermal and oxidative Stress responses in estuarine fish. Comparative Biochemistry and Physiology - A Molecular and Integrative Physiology, 166, 237-243.

Maloyan, A., \& Horowitz, M. (2002). $\beta$-Adrenergic signaling and thyroid hormones affect HSP72 expression during heat acclimation. Journal of Applied Physiology, 93, 107-115.

Marcos-López, M., Gale, P., Oidtmann, B. C., \& Peeler, E. J. (2010). Assessing the impact of climate change on disease emergence in freshwater fish in the United kingdom. Transboundary and Emerging Diseases, 57, 293-304.

Margulis, B. A., Anthropova, O., \& Kharazova, A. D. (1989). 70 KDa Heat Shock Proteins from Mollusc and human cells have common structural and functional domains. Comparative Biochemistry and Physiology - B Biochemistry and Molecular Biology, 94, 621-623.

Martínez, D., Vargas-Lagos, C., Oyarzún, R., Loncoman, C. A., Pontigo, J. P., Yáñez, A. J., \& Vargas-Chacoff, L. (2018). Temperature Modulates the Immunological Response of the SubAntarctic Notothenioid Fish Eleginops Maclovinus Injected with Piscirickettsia Salmonis. Fish and Shellfish Immunology, 82, 492-503.

Mateus, A. P., Costa, R. A., Cardoso, J. C. R., Andree, K. B., Estévez, A., Gisbert, E., \& Power, D. M. (2017a). Thermal imprinting modifies adult stress and innate immune responsiveness in the teleost sea bream. Journal of Endocrinology, 233, 381-394.

Mateus, A. P., Costa, R., Gisbert, E., Pinto, P. I. S., Andree, K. B., Estévez, A., \& Power, D. M. (2017b). Thermal imprinting modifies bone homeostasis in cold-challenged sea bream (Sparus aurata). Journal of Experimental Biology, 220, 3442-3454.

Meehl, G. A., \& Tebaldi, C. (2004). More intense, more frequent, and longer lasting heat waves in the 21st century. Science, 305, 994-997.

Meka, J. M., \& McCormick, S. D. (2005). Physiological response of wild Rainbow trout to angling: Impact of angling duration, fish size, body condition, and temperature. Fisheries Research, 72, 311-322.

Milligan, C. L., Graham, M. S., \& Farrell, A. P. (1989). The response of trout red cells to adrenaline during seasonal acclimation and changes in temperature. Journal of Fish Biology, 35, 229-236.

Mills, S. C., Beldade, R., Chabanet, P., Bigot, L., O’Donnell, J. L., \& Bernardi, G. (2015). Ghosts of thermal past: reef fish exposed to historic high temperatures have heightened stress response to further stressors. Coral Reefs, 34, 1255-1260. 
Mommsen, T. P., Vijayan, M. M., \& Moon, T. W. (1999). Cortisol in teleosts: Dynamics , mechanisms of action , and metabolic regulation. 211-268.

Mravec, B. (2011). Role of catecholamine-induced activation of vagal afferent pathways in regulation of sympathoadrenal system activity: negative feedback loop of stress response. Endocrine regulations, 45, 37-41.

Navarro, J. M., Paschke, K., Ortiz, A., Vargas-Chacoff, L., Pardo, L. M., \& Valdivia, N. (2019). The Antarctic fish Harpagifer antarcticus under current temperatures and salinities and future scenarios of climate change. Progress in Oceanography, 174, 37-43.

Neubauer, P., \& Andersen, K. H. (2019). Thermal performance of fish Is explained by an interplay between physiology, behaviour and ecology. Conservation Physiology, 7, 1-14.

Nivelle, R., Gennotte, V., Kalala, E. J. K., Ngoc, N. B., Muller, M., Mélard, C., \& Rougeot, C. (2019). Temperature preference of Nile tilapia (Oreochromis niloticus) juveniles induces spontaneous sex reversal. PLoS ONE, 14, 1-19.

Norin, T., \& Clark, T. D. (2016). Measurement and relevance of maximum metabolic rate in fishes. Journal of Fish Biology, 88, 122-151.

Noyes, P. D., McElwee, M. K., Miller, H. D., Clark, B. W., Van Tiem, L. A., Walcott, K. C., ... Levin, E. D. (2009). The toxicology of climate change: environmental contaminants in a warming world. Environment International, 35, 971-986.

Øverli, Ø., Winberg, S., \& Pottinger, T. G. (2005). Behavioral and neuroendocrine correlates of selection for stress responsiveness in Rainbow trout. Integrative and comparative biology, 45, 463-474.

Øverli, Ø., Korzan, W. J., Larson, E. T., Winberg, S., Lepage, O., Pottinger, T. G., ... Summers, C. H. (2004). Behavioral and neuroendocrine correlates of displaced aggression in trout. Hormones and Behavior, 45, 324-329.

Øverli, Ø., Kotzian, S., \& Winberg, S. (2002). Effects of cortisol on aggression and locomotor activity in Rainbow trout. Hormones and Behavior, 42, 53-61.

ula, J. R., Repolho, T., Pegado, M. R., Thörnqvist, P.-O., Bispo, R., Winberg, S., ... Rosa, R. (2019). Neurobiological and behavioural responses of cleaning mutualisms to ocean warming and acidification. Scientific Reports, 9, 0-10.

Pauly, D. (1980). On the interrelationships between natural mortality, growth parameters, and mean environmental temperature in 175 fish stocks. ICES Journal of Marine Science, 39, 175-192.

Payne, M. R. (2013). Climate change at the dinner table. Nature, 497, 365-366.

Perry, S. F., \& Reid, S. G. (1994). The effects of acclimation temperature on the dynamics of catecholamine release during acute hypoxia in the Rainbow trout Oncorhynchus Mykiss. Journal of Experimental Biology, 186, 289-307.

Petitjean, Q., Jean, S., Gandar, A., Côte, J., Laffaille, P., \& Jacquin, L. (2019). Stress responses in 
fish: From molecular to evolutionary processes. Science of the Total Environment, 684, 371380.

Piggott, J. J., Townsend, C. R., \& Matthaei, C. D. (2015). Reconceptualizing synergism and antagonism among multiple stressors. Ecology and Evolution, 5, 1538-1547.

Pilakouta, N., Killen, S. S., Kristjánsson, B. K., Skúlason, S., Lindström, J., Metcalfe, N. B., \& Parsons, K. J. (2020). Multigenerational exposure to elevated temperatures leads to a reduction in standard metabolic rate in the wild. Functional Ecology, 1-10.

Pinsky, M. L., Eikeset, A. M., McCauley, D. J., Payne, J. L., \& Sunday, J. M. (2019). Greater vulnerability to warming of marine versus terrestrial ectotherms. Nature, 569, 108-111.

Pörtner, H. O., \& Farrell, A. P. (2008). Physiology and climate change. Science, 322, 690-692.

Pörtner, H. O., \& Knust, R. (2007). Climate change affects marine fishes through the oxygen limitation of thermal tolerance. Science, 315, 95-97.

Puglisi-allegra, S., \& Andolina, D. (2015). Serotonin and stress coping. Behavioural Brain Research, 277, 58-67.

Redfern, J. C., Cooke, S. J., Lennox, R. J., Nannini, M. A., Wahl, D. H., \& Gilmour, K. M. (2017). Effects of maternal cortisol treatment on offspring size, responses to stress, and anxiety-related behavior in wild largemouth bass (Micropterus salmoides). Physiology and Behavior, 180, $15-24$.

Roberts, R., Agius, C., Saliba, C., Bossier, P., \& Sung, Y. Y. (2010). Heat shock proteins (Chaperones) in fish and shellfish and their potential role in relation to fish health: A review. Journal of Fish Diseases, 33, 789-801.

Ryan, S. N. (1995). The effect of chronic heat stress on cortisol levels in the Antarctic fish Pagothenia borchgrevinki. Experientia, 51, 768-774.

Ryu, T., Veilleux, H. D., Donelson, J. M., Munday, P. L., \& Ravasi, T. (2018). The epigenetic landscape of transgenerational acclimation to ocean warming. Nature Climate Change, 8 , 504-509.

Sadoul, B., \& Geffroy, B. (2019). Measuring cortisol, the major stress hormone in fishes. Journal of Fish Biology, 94, 540-555.

Sadoul, B., \& Vijayan, M. M. (2016). Stress and growth. In Fish Physiology pp. 167-205 Elsevier Inc.

Samaras, A., Papandroulakis, N., Lika, K., \& Pavlidis, M. (2018). Water temperature modifies the acute stress response of European sea bass, Dicentrarchus labrax L. (1758). Journal of Thermal Biology, 78, 84-91.

Sandblom, E., Clark, T. D., Gräns, A., Ekström, A., Brijs, J., Sundström, L. F., ... Jutfelt, F. (2016). Physiological constraints to climate warming in fish follow principles of plastic floors and concrete ceilings. Nature Communications, 7, 1-8. 
Schreck, C. B., \& Tort, L. (2016). The concept of stress in fish. In Fish physiology pp. 1-34 Elsevier.

Shatilina, Z. M., Wolfgang Riss, H., Protopopova, M. V., Trippe, M., Meyer, E. I., Pavlichenko, V. V., ... Timofeyev, M. A. (2011). The role of the heat shock proteins (HSP70 and SHSP) in the thermotolerance of freshwater amphipods from contrasting habitats. Journal of Thermal Biology, 36, 142-149.

Sih, A. (2013). Understanding variation in behavioural responses to human-induced rapid environmental change: A conceptual overview. Animal Behaviour, 85, 1077-1088.

Somero, G. N. (2004). Adaptation of enzymes to temperature: Searching for basic 'strategies'. Comparative Biochemistry and Physiology - B Biochemistry and Molecular Biology, 139, 321-333.

Somero, G. N. (2010). The Physiology of Climate Change: How potentials for acclimatization and genetic adaptation will determine 'winners' and 'losers'. Journal of Experimental Biology, 213, 912-920.

Steinbacher, P., Marschallinger, J., Obermayer, A., Neuhofer, A., Sänger, A. M., \& Stoiber, W. (2011). Temperature-dependent modification of muscle precursor cell behaviour is an underlying reason for lasting effects on muscle cellularity and body growth of teleost fish. Journal of Experimental Biology, 214, 1791-1801.

Steinhausen, M. F., Sandblom, E., Eliason, E. J., Verhille, C., \& Farrell, A. P. (2008). The effect of acute temperature increases on the cardiorespiratory performance of resting and swimming Sockeye salmon (Oncorhynchus nerka). Journal of Experimental Biology, 211, 3915-3926.

Stiasny, M. H., Sswat, M., Mittermayer, F. H., Falk-Petersen, I. B., Schnell, N. K., Puvanendran, V., ... Clemmesen, C. (2019). Divergent responses of Atlantic cod to ocean acidification and food limitation. Global Change Biology, 25, 839-849.

Tort, L. (2011). Stress and immune modulation in fish. Developmental and Comparative Immunology, 35, 1366-1375.

Tsai, C. L., \& Wang, L. H. (1997). Effects of thermal acclimation on the neurotransmitters, serotonin and norepinephrine in the discrete brain of male and female tilapia, Oreochromis mossambicus. Neuroscience Letters, 233, 77-80.

Tsoukali, S., Visser, A. W., \& MacKenzie, B. R. (2016). Functional responses of north Atlantic fish eggs to increasing temperature. Marine Ecology Progress Series, 555, 151-165.

Vargas-Chacoff, L., Arjona, F. J., Ruiz-Jarabo, I., García-Lopez, A., Flik, G., \& Mancera, J. M. (2020). Water temperature affects osmoregulatory responses in Gilthead sea bream (Sparus aurata L.). Journal of Thermal Biology, 88, 102526.

Vargas-Chacoff, L., Muñoz, J. L. P., Ocampo, D., Paschke, K., \& Navarro, J. M. (2019). The effect of alterations in salinity and temperature on neuroendocrine responses of the Antarctic fish Harpagifer antarcticus. Comparative Biochemistry and Physiology-Part A : Molecular and 
Integrative Physiology, 235, 131-137.

Varsamos, S., Flik, G., Pepin, J. F., Bonga, S. E. W., \& Breuil, G. (2006). Husbandry Stress during Early Life stages affects the stress response and health status of juvenile sea bass, Dicentrarchus labrax. Fish \& shellfish immunology, 20, 83-96.

Vasseur, D. A., DeLong, J. P., Gilbert, B., Greig, H. S., Harley, C. D. G., McCann, K. S., ... O’Connor, M. I. (2014). Increased temperature variation poses a greater risk to species than climate warming. Proceedings of the Royal Society B: Biological Sciences, 281.

Vindas, M. A., Fokos, S., Pavlidis, M., Höglund, E., Dionysopoulou, S., Ebbesson, L. O. E., ... Dermon, C. R. (2018). Early life stress induces long-term changes in limbic areas of a teleost fish: The role of catecholamine systems in stress coping. Scientific Reports, 8, 1-12.

Wassink, L., Bussy, U., Li, W., \& Sribner, K. (2019). High-stress rearing temperature in Acipenser fulvescens affects physiology, behaviour and predation rates. Animal Behaviour, 157, 153167.

Wendelaar Bonga, S. E. (1997). The stress response in fish. Physiological Reviews, 77, 591-625.

Whitney, C. K., Hinch, S. G., \& Patterson, D. A. (2013). Provenance matters: Thermal reaction norms for embryo survival among Sockeye salmon Oncorhynchus Nerka populations. Journal of Fish Biology, 82, 1159-1176.

Winberg, S., Nilsson, A., Hylland, P., Söderstöm, V., \& Nilsson, G. E. (1997). Serotonin as a regulator of hypothalamic-pituitary-interrenal activity in teleost fish. Neuroscience Letters, 230, 113-116.

Yada, T., \& Tort, L. (2016). Stress and disease resistance: Immune system and immunoendocrine interactions. In Fish Physiology pp. 365-403 Elsevier Inc.

Zhang, T. Y., Hellstrom, I. C., Bagot, R. C., Wen, X., Diorio, J., \& Meaney, M. J. (2010). Maternal care and DNA methylation of a glutamic acid decarboxylase 1 promoter in rat hippocampus. Journal of Neuroscience, 30, 13130-13137. 


\section{Significance statement}

Global warming is affecting fishes worldwide, through chronic temperature elevation and an increased frequency of extreme heatwaves. The consequences of these changes for stress physiology are, however, poorly addressed. This review provides an overview of information about the effects of temperature elevation (acute or chronic) on fish stress physiology, mainly obtained in controlled experimental conditions, and discusses the potential consequences for performance and fitness in the context of global warming. 
Table 1. Cortisol release as a function of elevated temperature experience.

\begin{tabular}{|c|c|c|c|}
\hline $\begin{array}{l}\text { Common name } \\
\text { (Scientific name) }\end{array}$ & Temperature experience & Cortisol release & Reference \\
\hline $\begin{array}{l}\text { Zebrafish (Danio } \\
\text { rerio) }\end{array}$ & $\begin{array}{l}10 \text { min - sudden change from } \\
28.5 \text { to } 36^{\circ} \mathrm{C}\end{array}$ & Increased level & Yeh et al., 2013 \\
\hline $\begin{array}{l}\text { Senegalese sole } \\
\text { (Solea } \\
\text { senegalensis) }\end{array}$ & $\begin{array}{l}10 \text { min - sudden change from } \\
20 \text { to } 25^{\circ} \mathrm{C}\end{array}$ & Increased level & $\begin{array}{l}\text { Conde-Sieira et } \\
\text { al., } 2018\end{array}$ \\
\hline $\begin{array}{l}\text { Black Sea trout } \\
(\text { Salmo trutta } \\
\text { labrax) }\end{array}$ & $\begin{array}{l}30 \text { min - sudden change from } \\
15 \text { to } 25^{\circ} \mathrm{C}\end{array}$ & Increased level & $\begin{array}{l}\text { Dengiz Balta et } \\
\text { al., } 2017\end{array}$ \\
\hline $\begin{array}{l}\text { Haddock } \\
\text { (Melanogrammus } \\
\text { aeglefinus) }\end{array}$ & $\begin{array}{l}1 \text { hour - sudden change from } \\
10 \text { to } 15^{\circ} \mathrm{C}\end{array}$ & Increased level & $\begin{array}{l}\text { Afonso et al., } \\
2008\end{array}$ \\
\hline $\begin{array}{l}\text { Rainbow trout } \\
\text { (Oncorhynchus } \\
\text { mykiss) }\end{array}$ & $\begin{array}{l}1 \text { hour - sudden change from } \\
13 \text { to } 25^{\circ} \mathrm{C}\end{array}$ & Increased level & $\begin{array}{l}\text { LeBlanc et al., } \\
2011\end{array}$ \\
\hline $\begin{array}{l}\text { Rainbow trout } \\
(\text { Oncorhynchus } \\
\text { mykiss) }\end{array}$ & $\begin{array}{l}2 \text { hour - sudden change from } \\
10 \text { to } 22{ }^{\circ} \mathrm{C}\end{array}$ & Increased level & Basu et al., 2001 \\
\hline $\begin{array}{l}\text { Mozambique tilapia } \\
\text { (Oreochromis } \\
\text { mossambicus) }\end{array}$ & $\begin{array}{l}2 \text { hour - sudden change from } \\
22 \text { to } 34{ }^{\circ} \mathrm{C}\end{array}$ & Increased level & Basu et al., 2001 \\
\hline $\begin{array}{l}\text { Rohu (Labeo } \\
\text { rohita) }\end{array}$ & $\begin{array}{l}2 \text { hours - sudden change from } \\
28 \text { to } 38^{\circ} \mathrm{C}\end{array}$ & Increased level & Kumar et al., 2015 \\
\hline $\begin{array}{l}\text { Goldfish } \\
\text { (Carassius auratus) }\end{array}$ & $\begin{array}{l}1 \text { hour - from } 19 \text { to } 31^{\circ} \mathrm{C} \\
\left(10^{\circ} \mathrm{C} \text { per hour }\right)\end{array}$ & Increased level & $\begin{array}{l}\text { Cockrem et al., } \\
2019\end{array}$ \\
\hline $\begin{array}{l}\text { Atlantic cod } \\
(\text { Gadus morhua })\end{array}$ & $\begin{array}{l}2 \text { hours - from } 10 \text { to } 22^{\circ} \mathrm{C} \\
\left(2^{\circ} \mathrm{C} \text { per hour }\right)\end{array}$ & Increased level & $\begin{array}{l}\text { Pérez-Casanova et } \\
\text { al., } 2008\end{array}$ \\
\hline $\begin{array}{l}\text { Sockeye salmon } \\
(\Omega / \text { corhynchus } \\
\text { nerka) }\end{array}$ & $\begin{array}{l}\text { From } 15 \text { to } 24^{\circ} \mathrm{C}\left(2^{\circ} \mathrm{C} \text { per }\right. \\
\text { hour })\end{array}$ & Increased level & $\begin{array}{l}\text { Steinhausen } \text { et al., } \\
2008\end{array}$ \\
\hline $\begin{array}{l}\text { Brook trout } \\
\text { (Salvelinus } \\
\text { fontinalis) }\end{array}$ & 6 hours - from 16 to $29^{\circ} \mathrm{C}$ & No change & $\begin{array}{l}\text { Chadwick et al., } \\
2015\end{array}$ \\
\hline $\begin{array}{l}\text { Sea bass } \\
\text { (Dicentrarchus } \\
\text { labrax) }\end{array}$ & $\begin{array}{l}4 \text { days - gradual increase } \\
\text { from } 16 \text { and } 21^{\circ} \mathrm{C}\end{array}$ & Increased level & $\begin{array}{l}\text { Goikoetxea } \text { et al., } \\
2021\end{array}$ \\
\hline $\begin{array}{l}\text { Sunshine bass } \\
\text { (Morone } \\
\text { chrysops } \times \text { Morone } \\
\text { saxatilis) }\end{array}$ & $\begin{array}{l}5 \text { days }-5-30^{\circ} \mathrm{C} \text { (by step of } 5 \\
{ }^{\circ} \mathrm{C} \text { ) }\end{array}$ & No change & Davis, 2004 \\
\hline $\begin{array}{l}\text { Senegalese sole } \\
\text { (Solea } \\
\text { senegalensis) }\end{array}$ & 7 days -24 vs $18{ }^{\circ} \mathrm{C}$ & $\begin{array}{l}\text { Increased level at } \\
1 \mathrm{~h} \text { and } 7 \text { days } \\
\text { but not within }\end{array}$ & $\begin{array}{l}\text { Benítez-Dorta et } \\
\text { al., } 2017\end{array}$ \\
\hline $\begin{array}{l}\text { Olive Flounder } \\
\text { (Paralichthys } \\
\text { Olivaceus) }\end{array}$ & $\begin{array}{l}2 \text { weeks - from } 20,22,24,26, \\
28 \text { and } 30^{\circ} \mathrm{C}\end{array}$ & $\begin{array}{l}\text { Increased level at } \\
1 \text { and } 2 \text { weeks } \\
\left(28 \text { and } 30^{\circ} \mathrm{C}\right)\end{array}$ & Kim et al., 2019 \\
\hline $\begin{array}{l}\text { European sea bass } \\
\text { (Dicentrarchus }\end{array}$ & 2 weeks $-15,20$ and $25^{\circ} \mathrm{C}$ & Increased level & $\begin{array}{l}\text { Samaras et al., } \\
2018\end{array}$ \\
\hline
\end{tabular}

This article is protected by copyright. All rights reserved. 


\begin{tabular}{|c|c|c|c|}
\hline labrax) & & & \\
\hline $\begin{array}{l}\text { Green } \\
\text { sturgeon (Acipenser } \\
\text { medirostris) }\end{array}$ & 2 weeks - 19 vs $11^{\circ} \mathrm{C}$ & No change & $\begin{array}{l}\text { Lankford et al., } \\
2003\end{array}$ \\
\hline $\begin{array}{l}\text { milkfish (Chanos } \\
\text { chanos) }\end{array}$ & 3 weeks -33 and $26^{\circ} \mathrm{C}$ & $\begin{array}{l}\text { Increased level } \\
\text { (scale) }\end{array}$ & Hanke et al., 2019 \\
\hline $\begin{array}{l}\text { Brook trout } \\
\text { (Salvelinus } \\
\text { fontinalis) }\end{array}$ & $\begin{array}{l}24 \text { days }-16-24^{\circ} \mathrm{C} \text { (by step of } \\
2^{\circ} \mathrm{C} \text { ) }\end{array}$ & Increased level & $\begin{array}{l}\text { Chadwick \& } \\
\text { McCormick, } 2017\end{array}$ \\
\hline $\begin{array}{l}\text { Atlantic salmon } \\
\text { (Salmo salar) }\end{array}$ & 4 weeks $-4,8,12$ and $17^{\circ} \mathrm{C}$ & $\begin{array}{l}\text { Increased level } \\
\text { (water) }\end{array}$ & $\begin{array}{l}\text { Madaro et al., } \\
2018\end{array}$ \\
\hline $\begin{array}{l}\text { Chinook salmon } \\
\text { (Oncorhynchus } \\
\text { tshawytscha) }\end{array}$ & 4 weeks $-7.5,12.5$ and $21^{\circ} \mathrm{C}$ & No change & $\begin{array}{l}\text { Barton \& Schreck, } \\
1987\end{array}$ \\
\hline $\begin{array}{l}\text { Trematomus } \\
\text { bernacchii }\end{array}$ & 4 weeks $--1.9,1.6$ and $3,8^{\circ} \mathrm{C}$ & No change & $\begin{array}{l}\text { Hudson } \text { et al., } \\
2008\end{array}$ \\
\hline $\begin{array}{l}\text { European sea bass } \\
\text { (Dicentrarchus } \\
\text { labrax) }\end{array}$ & 30 days $-8,16,24$ and $32^{\circ} \mathrm{C}$ & $\begin{array}{l}\text { Increased level at } \\
8 \text { and } 32^{\circ} \mathrm{C}\end{array}$ & Islam et al., 2020 \\
\hline $\begin{array}{l}\text { Sea bream (Sparus } \\
\text { aurata) }\end{array}$ & 35 days $-12,19$ and $26^{\circ} \mathrm{C}$ & Increased level & $\begin{array}{l}\text { Vargas-Chacoff et } \\
\text { al., } 2020\end{array}$ \\
\hline $\begin{array}{l}\text { Atlantic } \\
\text { cod (Gadus } \\
\text { morhua) }\end{array}$ & $\begin{array}{l}45 \text { days - from } 10 \text { to } 20^{\circ} \mathrm{C} \\
\left(1^{\circ} \mathrm{C} \text { every } 5 \text { days }\right)\end{array}$ & $\begin{array}{l}\text { Increased level } \\
\text { only at } 30 \text { days } \\
\left(16^{\circ} \mathrm{C}\right)\end{array}$ & $\begin{array}{l}\text { Pérez-Casanova et } \\
\text { al., } 2008\end{array}$ \\
\hline $\begin{array}{l}\text { Atlantic salmon } \\
\text { (Salmo salar) }\end{array}$ & 99 days $-12,16$ and $20^{\circ} \mathrm{C}$ & No change & Tromp et al., 2018 \\
\hline $\begin{array}{l}\text { European ea bass } \\
\text { (Dicentrarchus } \\
\text { labrax) }\end{array}$ & 4 months -16 and $21^{\circ} \mathrm{C}$ & Increased level & $\begin{array}{l}\text { Goikoetxea } \text { et al., } \\
2021\end{array}$ \\
\hline $\begin{array}{l}\text { Brook trout } \\
\text { (Salvelinus } \\
\text { Jontinalis) }\end{array}$ & River - from 18 to $23.3^{\circ} \mathrm{C}$ & Increased level & $\begin{array}{l}\text { Chadwick et al. } \\
2015\end{array}$ \\
\hline $\begin{array}{l}\text { Wild rainbow trout } \\
\text { (Oncorhynchus } \\
\text { mykiss) }\end{array}$ & River $-9.8,12.2$ and $13.2^{\circ} \mathrm{C}$ & $\begin{array}{l}\text { Tendency for } \\
\text { increased level }\end{array}$ & $\begin{array}{l}\text { Meka \& } \\
\text { McCormick, } 2005\end{array}$ \\
\hline $\begin{array}{l}\text { Lake sturgeon } \\
\text { (Acipenser } \\
\text { fulvescens) }\end{array}$ & $\begin{array}{l}\text { Embryo and larval - } 18 \text { vs } 10 \\
{ }^{\circ} \mathrm{C}\end{array}$ & $\begin{array}{l}\text { Tendency for } \\
\text { reduced level }\end{array}$ & $\begin{array}{l}\text { Wassink et al., } \\
2019\end{array}$ \\
\hline
\end{tabular}

This article is protected by copyright. All rights reserved. 
Table 2. Cortisol release upon acute stress at elevated temperature.

\begin{tabular}{|c|c|c|c|c|}
\hline $\begin{array}{l}\text { Common name } \\
\text { (Scientific name) }\end{array}$ & Temperature experience & Stressor & $\begin{array}{l}\text { Cortisol } \\
\text { release }\end{array}$ & Reference \\
\hline $\begin{array}{l}\text { Sockeye salmon } \\
(\text { Oncorhynchus nerka) }\end{array}$ & $\begin{array}{l}\text { From } 15 \text { to } 24^{\circ} \mathrm{C}\left(2^{\circ} \mathrm{C} \text { per }\right. \\
\text { hour })\end{array}$ & $\begin{array}{l}\text { Swimming } \\
\text { trial }\end{array}$ & $\begin{array}{l}\text { Increased } \\
\text { level }\end{array}$ & $\begin{array}{l}\text { Steinhausen } \\
\text { et al., } 2008\end{array}$ \\
\hline $\begin{array}{l}\text { Bald notothen } \\
\text { (Pagothenia } \\
\text { borchgrevinki) }\end{array}$ & $\begin{array}{l}\text { Thermal stress up to } 48 \mathrm{~h} \text { - } \\
5 \mathrm{vs}-1.9^{\circ} \mathrm{C}\end{array}$ & Confinement & $\begin{array}{l}\text { Greater } \\
\text { response } \\
\text { and long } \\
\text { lasting } \\
\end{array}$ & Ryan, 1995 \\
\hline $\begin{array}{l}\text { Sunshine bass } \\
(\text { Morone chrysops } \times \\
\text { Morone saxatilis) }\end{array}$ & $\begin{array}{l}5 \text { days }-5-30^{\circ} \mathrm{C} \text { (by step of } \\
\left.5^{\circ} \mathrm{C}\right)\end{array}$ & Confinement & $\begin{array}{l}\text { Faster and } \\
\text { greater } \\
\text { response }\end{array}$ & Davis, 2004 \\
\hline $\begin{array}{l}\text { Green } \\
\text { sturgeon (Acipenser } \\
\text { medirostris) }\end{array}$ & 2 weeks - 19 vs $11^{\circ} \mathrm{C}$ & Air exposure & $\begin{array}{l}\text { Faster } \\
\text { response }\end{array}$ & $\begin{array}{l}\text { Lankford } e t \\
\text { al., } 2003\end{array}$ \\
\hline $\begin{array}{l}\text { European sea bass } \\
\text { (Dicentrarchus } \\
\text { labrax) }\end{array}$ & 2 weeks $-15,20$ and $25^{\circ} \mathrm{C}$ & Confinement & $\begin{array}{l}\text { Faster } \\
\text { response } \\
\text { but reduced }\end{array}$ & $\begin{array}{l}\text { Samaras et } \\
\text { al., } 2018\end{array}$ \\
\hline $\begin{array}{l}\text { Atlantic salmon } \\
\text { (Salmo salar })\end{array}$ & $\begin{array}{l}4 \text { weeks }-4,8,12 \text { and } \\
17^{\circ} \mathrm{C}\end{array}$ & Confinement & $\begin{array}{l}\text { Greater } \\
\text { response } \\
\text { (water) }\end{array}$ & $\begin{array}{l}\text { Madaro et } \\
\text { al., } 2018\end{array}$ \\
\hline $\begin{array}{l}\text { Juvenile Chinook } \\
\text { salmon } \\
\text { (Oncorhynchus } \\
\text { tshawytscha) }\end{array}$ & $\begin{array}{l}4 \text { weeks }-7.5,12.5 \text { and } \\
21^{\circ} \mathrm{C}\end{array}$ & Handling & $\begin{array}{l}\text { Faster } \\
\text { recovery }\end{array}$ & $\begin{array}{l}\text { Barton \& } \\
\text { Schreck, } \\
1987\end{array}$ \\
\hline $\begin{array}{l}\text { Lake sturgeon } \\
\text { (Acipenser fulvescens) }\end{array}$ & $\begin{array}{l}\text { Embryo and larval - } 18 \text { vs } \\
10^{\circ} \mathrm{C}\end{array}$ & Alarm cue & $\begin{array}{l}\text { Reduced } \\
\text { response }\end{array}$ & $\begin{array}{l}\text { Wassink et } \\
\text { al., } 2019\end{array}$ \\
\hline $\begin{array}{l}\text { Wild rainbow trout } \\
\text { (Oncorhynchus } \\
\text { mykiss })\end{array}$ & $\begin{array}{l}\text { River }-9.8,12.2 \text { and } \\
13.2^{\circ} \mathrm{C}\end{array}$ & Handling & $\begin{array}{l}\text { Faster } \\
\text { response }\end{array}$ & $\begin{array}{l}\text { Meka \& } \\
\text { McCormick, } \\
2005\end{array}$ \\
\hline
\end{tabular}

This article is protected by copyright. All rights reserved. 


\section{Captions}

Figure 1. Stress response upon acute exposure to a sudden elevation in temperature. The diencephalon orchestrates the primary stress response by releasing catecholamines (mostly adrenaline and noradrenaline) through activation of brain-sympathetic-chromaffin cell (BSC) axis, and cortisol through the hypothalamo-pituitary-interrenal (HPI) axis into the bloodstream. In the immediate term, these hormones (catecholamines, orange and cortisol, blue) enhance activity of the cardiovascular system (e.g. increased heart rate and blood pressure) and rapidly mobilize energy (i.e. glucose, lactate; secondary response). In parallel, the release of catecholamines enhances the production of heat shock proteins (HSPs) that prevent and repair oxidative damage linked to the warming. Several minutes later, the cortisol release occurs and inhibits the production of HSPs, and acts as negative feedback control of further cortisol release. In the long term, these stress responses inhibit energy allocation to biological processes such as immunity, growth and reproduction, also called tertiary responses). Normal arrows represent an activation while bar-headed arrows represent an inhibition.

Figure 2. The hypothalamic-pituitary-interrenal axis (HPI) response under (a) acute temperature $\left(\mathrm{T}^{\circ}\right)$ increase, (b) chronic temperature elevation and (c) upon acute stressor at elevated temperature. rtisol release (lower panel) is illustrated according to the temperature protocol (upper panel, green lines; normal temperature conditions and red lines; elevated temperatures). The cortisol responses displayed in this figure are based on the studies mentioned in Tables 1 and 2.

Figure 3. Effect of temperature increase on energy allocation in a fish. (a) Assimilated food is placed reserve compartment and is then partitioned between structure and maturity after having paid for their respective maintenance costs (maint.). When temperature rises (b) all metabolic rates increase and physiological needs are met by increased food consumption. High temperature will put pressure on energy allocation (c) through increased costs for maintenance, leading to a reduction in allocation to structure and maturity.

This article is protected by copyright. All rights reserved. 


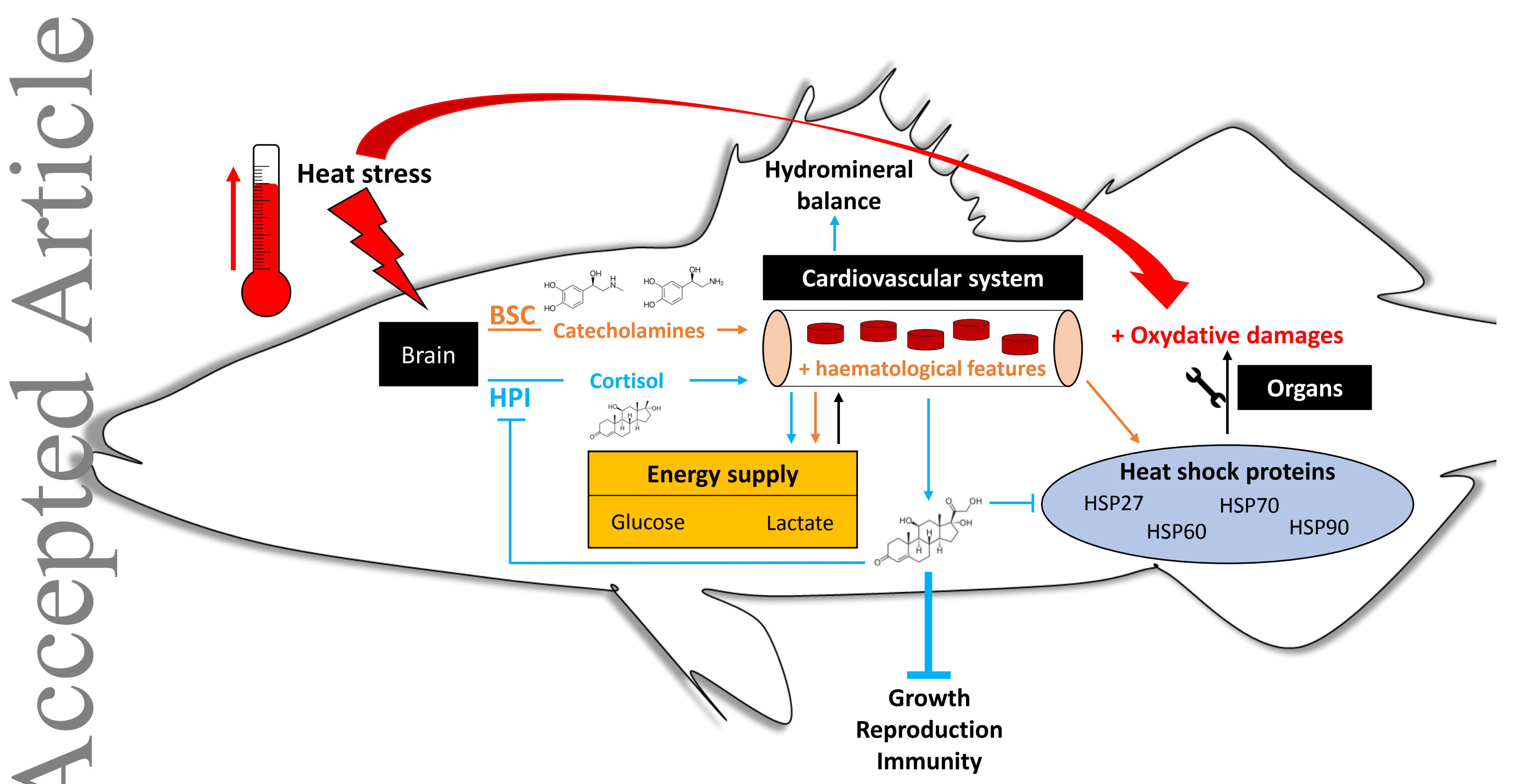




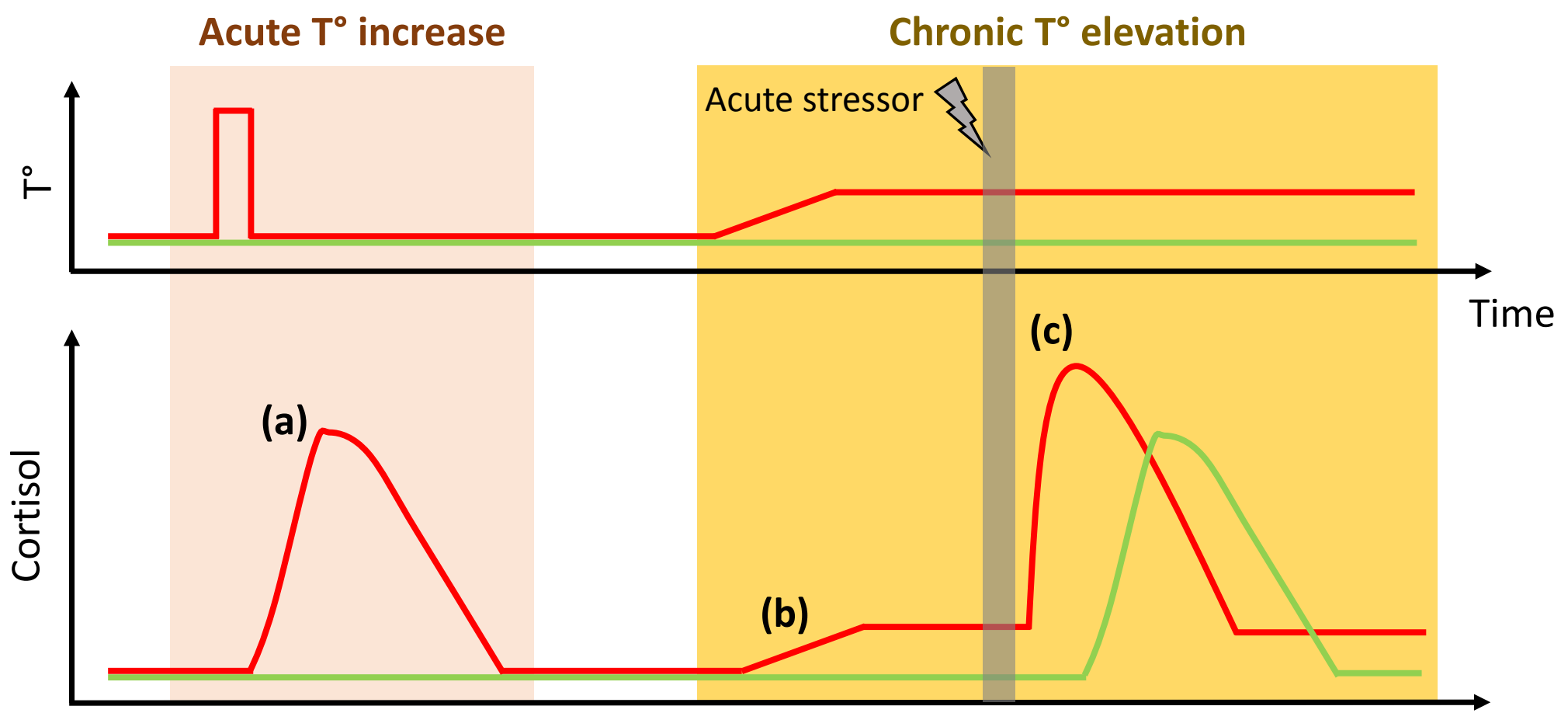




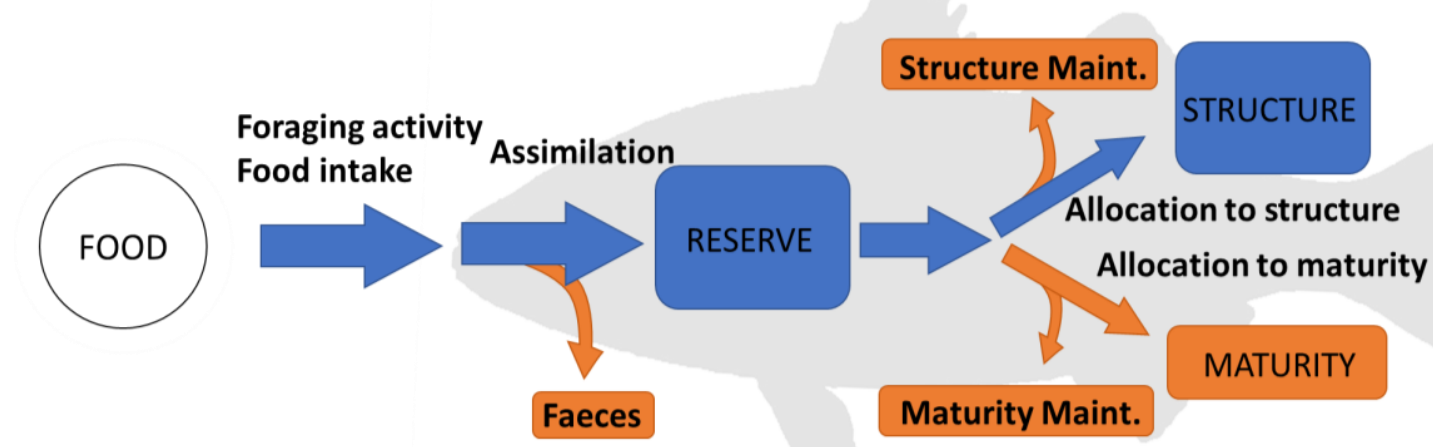

(b)
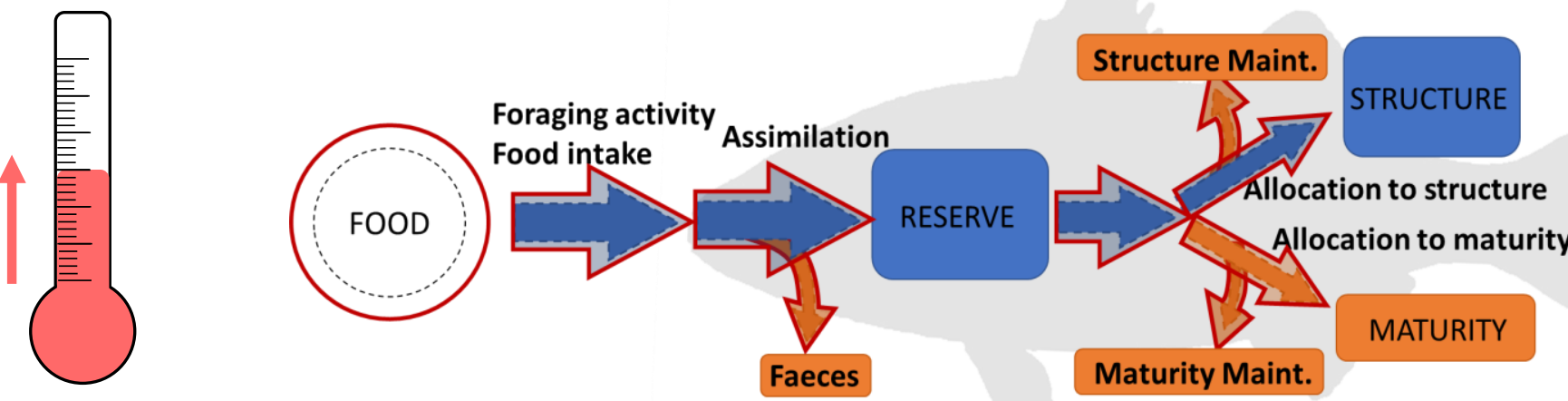

(c)
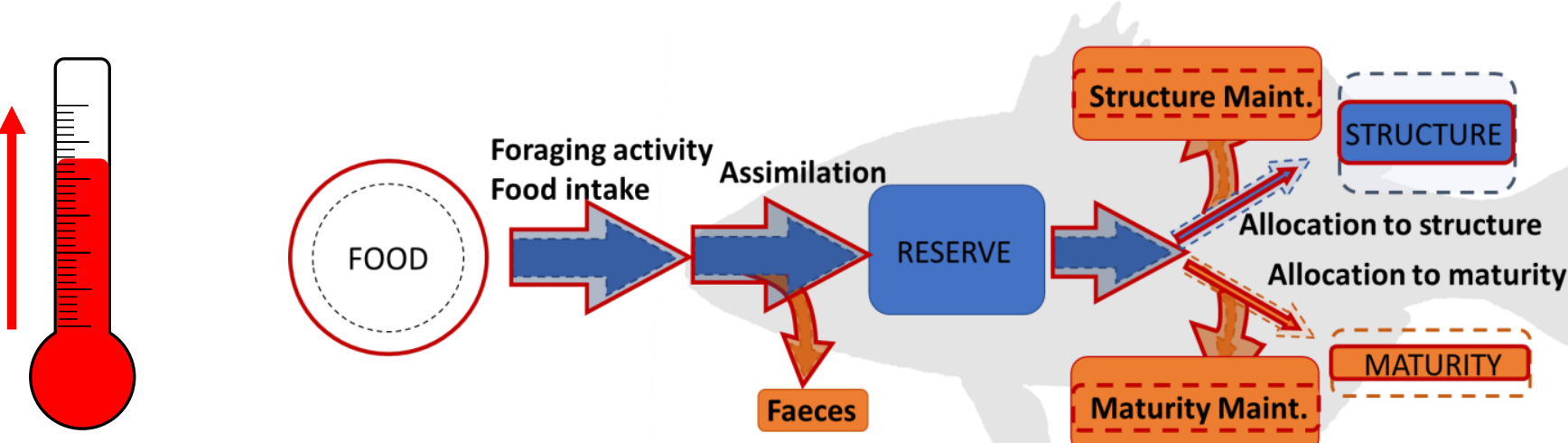

This article is protected by copyright. All rights reserved. 